\title{
MODEL OF ADAPTIVE MANAGEMENT OF FORMATION OF DIGITAL COMPETENCE BASICS OF PRIMARY SCHOOL STUDENTS
}

\author{
Katerina Kotelevets
}

The study is devoted to the issues of modeling the processes of adaptive management of the formation of digital competence of students in the process of obtaining primary education. The key aspects of the theoretical foundations of management of socio-pedagogical systems are revealed. Especially, the principles and approaches to management in general and adaptive in particular are described. It is described, that the essence of management of social and pedagogical systems consists in purposeful influences on the managed subsystem for its ordering. It is determined, that the main task of such management is to ensure the purposefulness, consistency of operation and development of the managed subsystem. The essence of adaptive management is specified, which, taking into account the main characteristics of classical management, is based on the processes of dialogic adaptation of managed and managing subsystems. The characteristics of the key definitions of the research are described, and the structure of the model of adaptive management of the process of formation of digital competence of students in the process of obtaining primary education is presented. The model consists of interconnected structural components, which together give an idea of the process of forming digital competence of students to ensure the success of their lives. The model was built on the basis of system and activity approaches using certain stages of the modeling process. The essence of four blocks of the model is described: target, theoretical, content-technological; and final-reflexive. It is noted, that the pedagogy of partnership is a key component of the formula of the New Ukrainian School and a component of the built model of adaptive management of the formation of digital competence of students in the process of obtaining primary education

Keywords: adaptive management, digital competence of students, modeling in education, quality of primary education

How to cite:

Kotelevets, K. (2021). Model of adaptive management of formation of digital competence basics of primary school students. ScienceRise: Pedagogical Education, 6 (45), 24-28. doi: http://doi.org/10.15587/2519-4984.2021.248257

(C) The Author(s) 2021

This is an open access article under the Creative Commons CC BY license hydrate

\section{Introduction}

Reforming general secondary education, in particular the introduction of the NUS Concept, is aimed at ensuring the quality of educational services, including in digital format. The introduction of blended learning and the unwillingness of participants in the educational process to it have determined the priority of research on the formation of digital competence of students in the process of obtaining primary education. To ensure the success of this process, it is necessary to exert appropriate influences on it. That is, any process must be managed.

The issue of adaptive management of the formation of digital competence of students in the process of obtaining primary education is relevant.

\section{Literary review}

The sources reveal the mechanisms of scientific research on the essence of adaptive management in education and describe the results of research, related to the introduction of adaptive management in educational practice [1]. As a component of adaptive management, scientists define the essence of adaptive management and the importance of adaptive mechanisms in assessing the project activities of educational institutions [2]. A thor- ough review of the scientific basis of adaptive management of general secondary education institutions helps to determine that adaptive management is a type of management, characterized by double passage of information through interacting structures: first downstream is normative and upward, bottom-up (at first social, moving bottom-up, then agreed information, which is normalized and moves to all actors of the socio-pedagogical system) [3]. Also, the literature defines such a characteristic feature of adaptive management as management, which is aimed at mutual adaptation and coordination of interdependent structures of the socio-pedagogical system [4]. Methodological aspects of adaptive processes in education are revealed; adaptability of the educational process in ensuring the quality of training in higher education institutions; adaptive technologies in the preparation of masters in the management of educational institutions; information analytics as a tool for regulating adaptive processes in education and in the organization of scientific research; adaptive education in preschool and general secondary education institutions, etc. The primary sources indicate the essence of adaptation processes, which is related to the development of the sociopedagogical system (educational institution) and the 
interaction of the institution with the external and internal environment. During such interaction, the institution shows adaptability. The activities of the institution are coordinated, taking into account regulatory requirements [5]. Aspects of professional competence of a teacher, taking into account digital challenges, are today a relevant and promising area of scientific research, but have not yet been fully explored [6]. The analysis of scientific sources gives grounds to assert that the issues of digital competence of students and the description of the processes of coordination of the activities of managing and managed subsystems remain unresolved. Therefore, it is advisable to analyze the possibilities of using adaptive management mechanisms in primary education. This can be done by creating a model of adaptive management of the formation of digital competence of students, receiving primary education.

At the same time, the analysis of scientific sources gives grounds to assert that the issues of formation of digital competence of students in the process of obtaining primary education and managing this process are insufficiently covered in primary sources.

\section{Aim and objectives of the study}

The aim of the study is to substantiate the identification of mechanisms of adaptive management of primary education and to develop technology for their use to form digital competence of students in the process of obtaining primary education.

To achieve this goal, the following tasks were set:

1. Formulate the main definitions of the study: "Digital competence of students in the process of obtaining primary education" and "Adaptive management of the formation of digital competence of students in the process of obtaining primary education."

2. Build a model of adaptive management of the formation of digital competence of students in the process of obtaining primary education.

3. Describe the main structural components of the constructed model.

\section{Materials and methods}

Modeling was used to design the model as the main method of studying pedagogical phenomena. The analysis clarified the characteristics of adaptive management mechanisms in education and detailed the procedure for their implementation. The combination of disparate knowledge about digital competence of participants in the educational process into understanding digital competence of primary school students was carried out using a method of cognition, such as synthesis. Systematization and classification as the leading research methods contributed to the establishment of the unity of disparate knowledge about adaptive approaches in education management and their division into groups according to certain characteristics. This contributed to the formulation of the characteristics of the system of adaptive management in primary education. Generalization, as the main method of deductive reasoning, was used to determine the nature and key content aspects of the phenomenon and key definitions: "Digital competence of students in primary education" and "Adaptive management of digital competence of students in the process of obtaining primary education" were formulated on this basis.

\section{Research results and their discussion}

The management process in a general secondary education institution is an integral part of the management of social systems. The essence of management of socio-pedagogical systems is purposeful influences on the managed subsystem for its ordering. The main task of such management is to ensure the purposefulness, consistency of operation and development of the managed subsystem. Adaptive management, taking into account the main characteristics of classical management, is based on the dialogic adaptation of the managing and managed subsystems.

The social system (including socio-pedagogical) has interconnected independent subsystems that are in constant interaction, in particular through the exchange of information (feedback). It is a management subject that exerts influence on a management object to ensure its necessary functioning and development. The success of such influences is linearly dependent on the principle of feedback of information flows, the essence of which is to determine the outcome of the impact and the effect, obtained from it. A developed social system also has a more developed feedback mechanism. In our case, the managed subsystem is the process of forming digital competence of students, receiving primary education. And the managing subsystem is a teacher, who exercises managerial influence to ensure the success of this process. Such influences, together, constitute a management process, which is characterized by appropriate functions that provide influence on the managed system in order to streamline it and direct it to obtain the planned result.

Consider the essence of digital competence of students in the process of obtaining primary education and reveal the process of its formation.

Digital competence is considered as a set of skills in working with information in all its representations and forms and skills to use information and communication technologies both in professional activities and in everyday life [7-9]. We agree with scientists who note that information competence should be understood as a certain quality of personality, readiness, knowledge and skills to work with information through the use of information and communication technologies. Also, the authors argue that this is a certain ability of an individual to use information technology to solve any problem in general and to independently master the knowledge of information [9].

Under digital competence of students in the process of obtaining primary education we will understand the willingness and ability of an individual to use information and communication technologies in order to master the content of primary education.

Students' digital competence is closely linked to digital culture. The scientist notes that free orientation in the information space involves the formation of an appropriate level of information culture as one of the components of culture in general [10]. Given the above, we will consider digital competence of students from the standpoint of information culture. Information culture is a system of values and patterns of individual behavior. 
These models characterize the life of an individual in the digital space.

Adaptive management of the process of forming the foundations of digital competence of students in the process of obtaining primary education is understood as a purposeful, coordinated influence of the subject of management on the object of management to ensure the success of an individual in the digital educational space.

Consider the process of building and components of adaptive management models of the process of forming digital competence of students in the process of obtaining primary education.

Modeling in educational systems is aimed at solving current problems of quality assurance. The content of education and educational interaction of the subjects of the educational process are modeled. Such models are called didactic and consist of such components as pedagogical technologies, methods, organizational forms of learning, etc. In addition, an educational model and its varieties are popular: imitation, semiotic, social [4]. An educational model is a logical consistent system of interconnected elements that have goals, objectives, including the content of education, pedagogical technologies and technologies for managing the educational process. They may also include elements of an educational program of an institution and key competencies of learners. The task of this model is to build an educational program of an institution and design the development of life skills of students. It may also include criteria for technology effectiveness, descriptions of control arrangements and assessment, and so on.

The study used systematic and activity approaches to model creation, using certain stages of the modeling process. Namely: formulation of the purpose of model creation; identification of structural components and establishing links between their interaction; determination of criteria for obtaining information and the procedure of data evaluation, their fixation for storage and further use, the expected result.

The construction of the model of adaptive management of the formation of digital competence of students in the process of obtaining primary education is carried out, taking into account the classical stages of modeling. Schematically, the model is presented in Fig. 1.

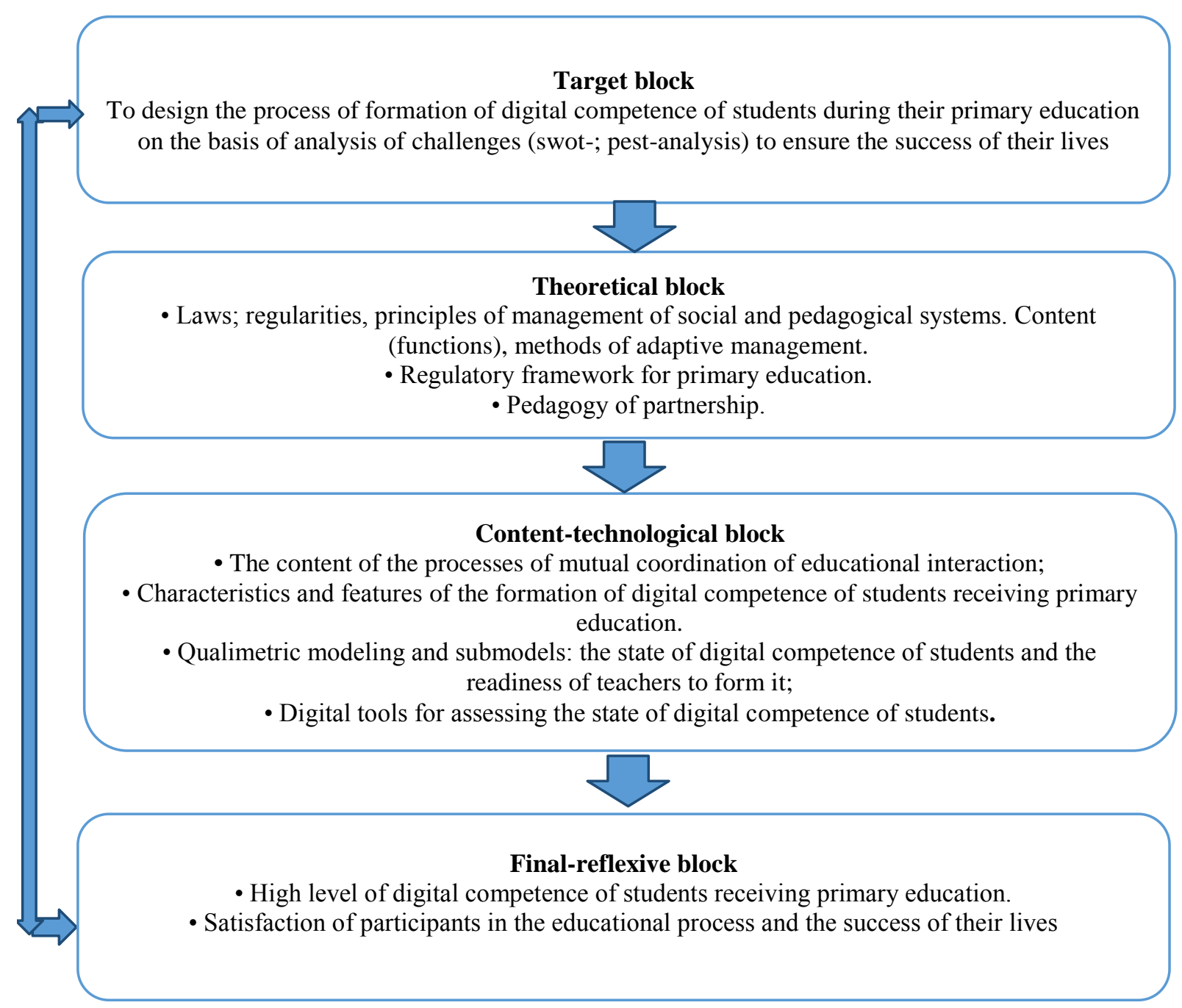

Fig. 1. Model of adaptive management of the formation of the basics of digital competence of primary school students 
We will reveal some characteristics of the above model. The model consists of such structural components as:

- target block, which includes the strategic goal and its decomposition into tasks.

- theoretical block, which includes the theoretical foundations of adaptive management of the formation of digital competence of students in the process of obtaining primary education;

- content-technological block, which includes the characteristics of the interaction of the subject and the object of management and describes the procedure for measuring the state of digital competence of students in the process of obtaining primary education and step-bystep actions for its formation;

- final-reflective block, which includes a description of the result and the development of further actions to improve digital competence of students in the process of obtaining primary education.

Management of socio-pedagogical systems can be considered as a purposeful influence of the managing system (in our case, such an influence is exerted by a teacher) on the motivational aspects of students in the implementation of educational activities and the formation of digital competence. In the scientific literature, such influence is defined as the process of bringing the object of management in line with its inherent patterns of activity and functions that it performs [4, 11]. It should be emphasized, that such an impact is also one that ensures the quality of the educational process to obtain the most positive result in the formation of digital competence of students. However, given the peculiarities of adaptive management, it should be emphasized, that such influence is based on the mutually agreed purpose of participants in the educational process. Any management, including adaptive, has its own laws, principles, functions, etc. It is based on scientific approaches, such as anthroposocial (at the heart of such management human and his/her needs); system approach (consideration of the object of management in the aggregate of its components); synergetic approach (self-organization and interaction in conditions of instability); qualimetric approach (to determine qualitative indicators of change through quantity).

Leading is the use of partnership pedagogy, which is a key component of the New Ukrainian School formula. The pedagogy of partnership is based on mutual respect of participants in the educational process for each other. It is believed, that such pedagogy is based on personality-oriented learning, at the center of which is the uniqueness of individual mechanisms of development of the child's personality. Based on the work of scientists, we can identify the main characteristics of the use of partnership pedagogy: the organization of the educational process and planning of educational material in primary school should take into account the internal needs of students, their personal abilities, personal experience, general level of development; revealing ways of their selfdevelopment of students; control and assessment of students' academic achievements is carried out using multilevel, differentiated tasks, based on self-control, self-assessment and self-correction of student actions.
We emphasize that the learning process, especially in primary school, is a joint activity of teacher and student based on the recognition of individual characteristics of a student, the level of his/her academic achievements, the state of learning motivation. Personalityoriented pedagogical technologies and methodological systems of teaching are used in partnership pedagogy.

Leading in the management of socio-pedagogical systems is the consideration of certain principles as fundamental starting points, which follow from the stable trends of existence and development of a particular system. Adaptive management of the formation of digital competence of students in the process of obtaining primary education is based on such principles as: democratization, humanization, optimization, differentiation and openness. These principles recognize the development of a child as a priority and determine his/her natural path.

Also, the principles of feedback, information sufficiency, operational regulation, and analytical forecasting, which have an impact on the optimization of management decisions, should be mentioned as leading.

To ensure the quality of educational activities there are leading approaches to the organization of interaction of participants in the educational process as: systems, procedural, situational, which ensure optimal management of socio-pedagogical systems. The systems approach is based on the general theory of systems, which means that any managed object is considered as a set of interdependent elements, it has an "exit" (goal) of the system and "input" (resources), connection with the external environment, feedback, etc. only by considering the management process from the standpoint of the systems approach can you get an objective idea of the state of the managed system. Using the systems approach, the object of management is considered as a set of interdependent (interconnected) elements with certain properties that have a connection with both the external environment and the internal environment of an educational institution. Given this connection, it is possible to achieve effective coordination of the structural components of the system and ensure the achievement of the planned result. Taking into account the principle of feedback, the obtained result is compared with the goal that was determined and a decision is made on the degree of its achievement. We emphasize that the implementation of management on the basis of the systems approach is through the implementation of appropriate functions that have a system-forming nature, and their totality is the content of management.

The procedural approach is based on a logical scheme of performing a function as a series of actions that make up a certain process, the implementation of these actions (functions) determines the content of management.

The situational approach is based on the prompt response to the situation in its assessment, and when making a decision one must take into account the specific circumstances that affect the organization of activities at this time.

Revealing the characteristics of the model of adaptive management of the formation of digital competence of students, receiving primary education, it should be noted, that the effectiveness of any management ac- 
tions depends entirely on the information, received about the state of the object of management. Measuring the state of the object of management and comparing the current results (current state) with the desired is the basis of management of socio-pedagogical systems and is its essence. Any deviation from the desired state is the basis for the implementation of managerial influences. To conduct such measurements, we use a qualimetric approach and perform factor-criterion modeling.

The study does not cover all aspects of the issue. In particular, the mechanism for assessing the state of formation of digital competence of students is not described. Further research will consider the issue of factorcriterion modeling of the process of building a qualimetric model for assessing the state of digital competence of students in the process of obtaining primary education and describe the procedure for interpreting the results.

\section{Conclusions}

1. The study contributed to determining the characteristics of the system of adaptive management in primary education, the formulation of their essence. The content of the characteristics was generalized and on this basis a model of adaptive management of the formation of the basics of digital competence of primary school students was built. The design of the model contributed to the description of the structural components (blocks) of the model. These are the following blocks: target, theoretical, content-technological; and final-reflexive. The implementation of the model is based on the leading principles of management of socio-pedagogical systems and approaches to the organization of interaction of participants in the educational process in primary school.

2. In the course of the research the peculiarities of adaptive management in the primary level of education have been singled out. The main feature of which is the coherence of the goal of participants of the educational process. During the formation of the foundations of digital competence, the coherence of the goal provides a high motivation for learning activities of primary school students and contributes to the success of their lives.

3. The study provided a generalization of the essence of adaptive management in forming the foundations of digital competence of primary school students as a purposeful, coordinated influence of the subject of management on the object of management to ensure the success of an individual in the digital educational space.

\section{References}

1. Luzan, L. O., Pochuieva, O. O., Riabova, Z. V., Yelnykova, H. V., Rostoky, M. L. (Eds.) (2021). Adaptyvni protsesy v osviti. Kharkiv: Machulyn, 3, 160.

2. Bodnar, O., Ivasiv, O. (2020). The Structure of Self-assessment of the Project Activity in the Context of Adaptive Management. Image of the modern pedagogue, 1 (2), 9-14. doi: https://doi.org/10.33272/2522-9729-2020-2(191)-9-14 Kyiv, 641

3. Yelnykova, H. V. (2005). Naukovi osnovy adaptyvnoho upravlinnia zakladamy ta ustanovamy zahalnoi serednoi osvity.

4. Yelnykova, H. V., Borova, T. A., Riabova, Z. V., Pochuieva, O. O., Luzan, L. O., Rostoka, M. L. (2017). Adaptyvne upravlinnia: mizhhaluzevi zviazky, naukovo-prykladnyi aspekt. Kharkiv: Machulyn, 111.

5. Marmaza, O. I. (2017). Menedzhment osvitnoi orhanizatsii. Kharkiv: «Shchedra sadyba», 126.

6. Riabova, Z. V., Yelnykova, H. V. (2020). Professional growth of teachers in the conditions of digital education. Information Technologies and Learning Tools, 80 (6), 369-385. doi: https://doi.org/10.33407/itlt.v80i6.4202

7. Informatsiina kompetentnist fakhivtsia. Available at: https://sites.google.com/site/informacijnakompetentnist/

8. Kartashova, L., Kyrychenko, M., Sorochan, T. (2020). Antykryzovyi menedzhment pidvyshchennia kvalifikatsii. Herald of the National Academy of Educational Sciences of Ukraine, 2 (1). doi: https://doi.org/10.37472/2707-305x-2020-2-1-7-9

9. Semko, L. P., Lapinskyi, V. V. (2020). Informatsiini kompetentnosti ta shliakhy yikh formuvannia. Sotsialno-psykholohichni tekhnolohii rozvytku osobystosti. Kherson, 324-327. Available at: https://lib.iitta.gov.ua/719931/1/Semko_stattia\%202020.pdf

10. Kyrychenko, M. (2017). Formuvannia tsyfrovoi kultury yak rezultat rozvytku kultury informatsiinoho suspilstvaiu. Stanovlennia i rozvytok informatsiinoho suspilstva yak osnovy zabezpechennia konkurentospromozhnosti Ukrainy u sviti ta staloho rozvytku suspilstva i derzhavy. Kyiv, 34-36. Available at: https://old-zdia.znu.edu.ua/gazeta/mnkonf_34.pdf

11. Yelnykova, H., Ryabova, Z. (2021). Adaptive technologies for training of specialists. IOP Conference Series: Materials Science and Engineering, 1031 (1). doi: https://doi.org/10.1088/1757-899x/1031/1/012125

Received date 26.10.2021

Accepted date 25.11.2021

Published date 30.11.2021

Katerina Kotelevets, Postgraduate Student, Department of Education and Law Management, State Institution of Higher Education «University of Education Management» of the National Academy of Pedagogical Sciences of Ukraine, Sichovykh striltsiv str., 52 A, Kyiv, Ukraine, 04053

E-mail: Kotelevets1990@gmail.com 